\title{
KinerJa Keterlibatan Masyarakat \\ Dalam Sarana Prasarana Pariwisata Menurut \\ Community Based Tourism Pada Desa Wisata Berjo \\ NGARgoyoso Di KABUPATEN KRANGANYAR
}

\author{
Arvia Ari Sugesti, Galing Yudana, Winny Astuti \\ Program Studi Perencanaan Wilayah dan Kota, \\ Fakultas Teknik \\ Universitas Sebelas Maret, Surakarta \\ email: arvia.sugesti@yahoo.com
}

\begin{abstract}
Recently, a lot of tourism development focused on rural tourism, which relates issues of community based tourism. In community based tourism there are many aspects of the benchmarks, one of which related to community involvement in the tourism. Community involvement in the Tourism Village Berjo itself can be seen from tourist services sector, where business travel services is a tourism infrastructure facilities run by local residents. In the village of local residents participating businesses become tourist services and is active in a tourist community.

This study aimed to analyse the performance and the value of community involvement in community-based tourism infrastructure in the Tourism Village Berjo. Observations depth on the types of infrastructure of tourism and the involvement of the community is the first process of this study, further assessment of each community's involvement in every aspect means good infrastructure of tourism and demonstrate theories that Tourism Village Berjo has been referring to the principles of community based tourism as a theory by some experts. Results of the study indicate that the performance of community involvement in infrastructure community based tourism has a very high value (community involvement in tourism facilities lodging, catering, sales of souvenirs, public facilities in objects and tourist infrastructure of transportation, parking, institutional, information services). This is illustrated by the many businesses tourist infrastructure services which are local residents and their liveliness in a community, so from these things can be proved that tourism at the Tourism Village Berjo in accordance with the principles of community based tourism.
\end{abstract}

Keywords: Tourism, Rural tourism, Community-Based, Infrastructure tourism

\section{PENDAHULUAN}

Pada saat ini perkembangan pariwisata telah merambah dalam berbagai terminologi sepeti sustainable tourism development, village tourism dan ecotourism yang merupakan pendekatan pengembangan kepariwisataan yang mengupayakan agar wisata dapat dilaksanakan di daerah tujuan wisata bukan perkotaan, yakni di dalam suatu pedesaan. Suatu desa yang akan dijadikan ODTW (Obyek daerah tujuan wisata) harus memiliki potensi-potensi yang dapat dikembangkan yang berupa alam, adat-istiadat, budaya, tradisi, kerajinan, dan sebagainya.

Pengembangan obyek wisata dalam suatu pariwisata di sebuah desa sejatinya bertujuan untuk meningkatkan kesejahteraan dari masyarakat lokal yang diberdayakan dalam setiap tahap pengembangan obyek wisata tersebut atau lebih dikenal dengan community based tourism (CBT) atau pariwisata berbasis masyarakat. Pariwisata berbasis masyarakat merupakan sebuah pendekatan pemberdayaan yang melibatkan dan meletakkan masyarakat sebagai pelaku penting dalam konteks paradigma baru pembangunan (Sastrayuda, 2010).

Selain community based tourism yang membicarakan tentang keterlibatan masyarakat, perkembangan sarana prasarana pariwisata dalam suatu daerah dapat menjadi tolok ukur keberhasilan kegiatan wisata tersebut dapat dijalankan, karena peranan sarana prasarana pariwisata merupakan keharusan yang dapat memudahkan proses wisatawan dalam proses berwisata. Untuk itu fokus penelitian ini adalah keterlibatan 
masyarakat dalam sarana prasarana pariwisata yang berbasisi masyarakat.

Salah satu desa wisata di Kabupaten Karanganyar yang memiliki potensi unggul dalam bidang pariwisatanya adalah Desa Berjo. Desa Berjo memiliki potensi alam, sejarah, budaya maupun buatan yang sangat baik untuk dikembangkan. Selain itu Desa Berjo telah memiliki beberapa lembaga terkait kepariwisataan yang digerakkan oleh masyarakat setempat sendiri seperti: badan usaha milik desa, kelompok sadar wisata, di mana memiliki tugas membina masyarakat dalam pengelolaan pariwisata desa khususnya wisata alam yang menjadi wisata unggulan di desa tersebut. Selain memiliki lembaga kepariwisataan, Desa Berjo merupakan desa yang maju dengan sarana prasarana pariwisata yang ada dan dikelola langsung oleh masyarakat setempat. Hal itu dapat dilihat dari kelengkapan sarana prasarana yang dikelola langsung oleh masyrakat dan tetap dijaga fungsi serta kualitasnya.

Dengan demikian peran masyarakat dalam jasa usaha pariwisata tersebut merupakan salah satu ciri penting dari community based tourism yang dapat diulas sebagai bahan penelitian. Selanjutnya perlu adanya ulasan tentang bagaimana konsep CBT tersebut diterapkan melalui berbagai aspek wisatanya, salah satunya adalah penerapan dalam keterlibatan masyarakat dalam sarana prasarana pariwisata berbasis masyarakat di Desa Berjo Kecamatan Ngargoyoso Kabupaten Karanganyar.

Oleh karena itu penelitian ini bertujuan untuk mengidentifikasi kinerja keterlibatan masyarakat dalam sarana dan prasarana pariwisata di Desa Wisata Berjo dengan konsep community based tourism.

\section{METODE}

\section{A. Ruang Lingkup}

Ruang lingkup spasial penelitian ini adalah Desa Berjo, Kecamatan Ngargoyoso, Kabupaten Karanganyar. Desa Berjo merupakan merupakan salah satu desa di Kabupaten Karanganyar yang memiliki berbagai macam obyek wisata. Untuk fokus obyek wisata yang dipilih oleh peneliti adalah obyek wisata alam Grojogan Jumog dan Telaga madirda, karena salah satu ciri khas dari desa wisata adalah adanya wisata alam dan dari data awal yang diperoleh diketahui bahwa 2 obyek wisata alam tersebut dikembangkan secara mandiri oleh masyarakat setempat.

B. Metode Analisis

Analisis dilakukan dengan dua tahapan yaitu analisis kesiapan tiap variabel dengan teknik penilaian menggunakan presentase dari jumlah tiap variabelnya, kemudian hasil dari analisis tiap variabel keterlibatan masyarakat dalam sarana prasarana pariwisata tersebut menjadi input dari analisis prinsip community based torism. Untuk menentukan nilai hasil keterlibatan, digunakan nilai interval dalam 4 tingkatan, yaitu:

$$
\begin{array}{lll}
0 \%-24.9 \% & : & \text { Rendah } \\
25 \%-49.9 \% & : & \text { Sedang } \\
50 \%-74.9 \% & : & \text { Tinggi } \\
\geq 75 \% & : & \text { Sangat Tinggi }
\end{array}
$$

Berikut adalah gambaran variabel dan indikator yang menjelaskan keterkaitan antara jenis sarana prasarana pariwisata

\begin{tabular}{|c|c|c|c|c|}
\hline \multirow[t]{2}{*}{ Variabel } & \multicolumn{4}{|c|}{ Indikator } \\
\hline & Rendah & Sedang & Tinggi & $\begin{array}{l}\text { Sangat } \\
\text { Tinggi }\end{array}$ \\
\hline $\begin{array}{l}\text { Sarana } \\
\text { Penginapan }\end{array}$ & \multirow{4}{*}{$\begin{array}{l}0 \%-24.9 \% \\
\text { pelaku usaha } \\
\text { sarana } \\
\text { prasarana } \\
\text { merupakan } \\
\text { warga lokal. }\end{array}$} & \multirow{4}{*}{$\begin{array}{l}25 \% \text { - } 49.9 \% \\
\text { pelaku usaha } \\
\text { sarana } \\
\text { prasarana } \\
\text { merupakan } \\
\text { warga lokal. }\end{array}$} & \multirow{4}{*}{$\begin{array}{l}50 \%-74.9 \% \\
\text { pelaku usaha } \\
\text { sarana } \\
\text { prasarana } \\
\text { merupakan } \\
\text { warga lokal. }\end{array}$} & \multirow{4}{*}{$\begin{array}{l}\geq \quad 75 \% \\
\text { pelaku usaha } \\
\text { sarana } \\
\text { prasarana } \\
\text { merupakan } \\
\text { warga lokal. }\end{array}$} \\
\hline Sarana Boga & & & & \\
\hline \multirow{3}{*}{$\begin{array}{l}\text { Sarana } \\
\text { Penjualan } \\
\text { Oleh-oleh }\end{array}$} & & & & \\
\hline & & & & \\
\hline & \multirow{4}{*}{$\begin{array}{l}0 \%-24.9 \% \\
\text { sarana } \\
\text { penginapan } \\
\text { turut serta } \\
\text { dalam } \\
\text { komunitas. }\end{array}$} & \multirow{4}{*}{$\begin{array}{l}25 \%-49.9 \% \\
\text { sarana } \\
\text { penginapan } \\
\text { turut serta } \\
\text { dalam } \\
\text { komunitas. }\end{array}$} & \multirow{4}{*}{$\begin{array}{l}50 \%-74.9 \% \\
\text { sarana } \\
\text { penginapan } \\
\text { turut serta } \\
\text { dalam } \\
\text { komunitas. }\end{array}$} & \multirow{4}{*}{$\begin{array}{l}\geq \quad 75 \% \\
\text { sarana } \\
\text { penginapan } \\
\text { turut serta } \\
\text { dalam } \\
\text { komunitas. }\end{array}$} \\
\hline $\begin{array}{l}\text { Fasilitas di } \\
\text { lokasi obyek }\end{array}$ & & & & \\
\hline Transportasi & & & & \\
\hline \multirow[t]{2}{*}{ Perparkiran } & & & & \\
\hline & \multirow{3}{*}{$\begin{array}{l}\text { Penghasilan } \\
\text { rata-rata } \\
\text { pelaku usaha } \\
\text { penginapan } \\
\text { perbulan < } \\
1,1 \text { juta }\end{array}$} & \multirow{3}{*}{$\begin{array}{l}\text { Penghasilan } \\
\text { rata-rata pelaku } \\
\text { usaha } \\
\text { penginapan } \\
\text { perbulan } 1,2- \\
1,5 \text { juta }\end{array}$} & \multirow{3}{*}{$\begin{array}{l}\text { Penghasilan } \\
\text { rata-rata } \\
\text { pelaku usaha } \\
\text { penginapan } \\
\text { perbulan } 1,5 \\
-2 \text { juta }\end{array}$} & \multirow{3}{*}{$\begin{array}{l}\text { Penghasilan } \\
\text { rata-rata } \\
\text { pelaku usaha } \\
\text { penginapan } \\
\text { perbulan > } 2 \\
\text { juta }\end{array}$} \\
\hline $\begin{array}{l}\text { Kelembagaa } \\
\text { n Pariwisata }\end{array}$ & & & & \\
\hline $\begin{array}{l}\text { Jasa } \\
\text { informasi } \\
\text { pariwisata }\end{array}$ & & & & \\
\hline
\end{tabular}
dan keterlibatan masyarakat di dalam sarana prasarana pariwisata tersebut:

Tabel 1 Variabel Indikator

\section{HASIL DAN PEMBAHASAN}

\section{A. Analisis Kinerja Keterlibatan Masyarakat Dalam Sarana Wisata Penginapan menurut Community Based Tourism}

Analisis keterlibatan masyarakat dalam sarana wisata penginapan yang 
dilihat dari 2 aspek yakni identitas pelaku dan keikutsertaannya dalam komunitas. Dari hasil analisis tersebut dapat diketahui bahwa sebagian pelaku usaha sarana wisata penginapan baik pemilik maupun pekerja merupakan penduduk lokal Desa Berjo. Setelah dilakukan penilaian, disimpulkan bahwa untuk pelaku sarana wisata penginapan memiliki nilai rata-rata $81.9 \%$. Menurut rentang interval yang telah digunakan, $81.9 \%$ artinya memiliki nilai yang sangat tinggi.

Pemenuhan kriteria community based tourism dari segi sosial yaitu masyarakat lokal tersebut telah diberdayakan dan memegang peranan penting dalam aspek pengelolaan sarana wisata penginapan. Sedangkan pemenuhan kriteria community based tourism dari segi ekonomi yaitu angka pengangguran di wilayah tersebut semakin berkurang dengan adanya lapangan pekerjaan yang membuka peluang kerja bagi masyarakat setempat untuk menjadi pemilik sarana penginapan maupun pekerjanya. Hal tersebut secara tidak langsung juga dapat meningkatkan pendapatan masyarakatnya.

Dari beberapa kesimpulan di atas, dapat diketahui kesimpulan akhir dari penelitian ini adalah bahwa keterlibatan masyarakat dalam sarana prasarana pariwisata di desa wisata Berjo telah mengacu pada prinsip-prinsip community based tourism, sesuai dengan teori-teori yang memiliki arti community based tourism.

B. Analisis Kinerja Keterlibatan Masyarakat Dalam Sarana Wisata Boga menurut Community Based Tourism

Usaha boga yang dipilih adalah usaha boga yang terdapat di dalam obyek wisata Grojogan Jumog dan Telaga Madirda yang menjadi fokus obyek penelitian dan Keterlibatan masyarakat dalam sarana wisata boga dilihat dari 2 aspek, yakni identitas pelaku dan keikutsertaannya dalam komunitas.

Setelah dilakukan penilaian, disimpulkan bahwa untuk pelaku sarana wisata boga yeng berupa keterlibatan masyarakat maupun keikutsertaannya dalam komunitas memiliki nilai rata-rata 98.5\%. Menurut rentang interval yang telah digunakan, $98.5 \%$ artinya memiliki nilai yang sangat tinggi atau berarti keterlibatan masyarakat dalam sarana boga sangat tinggi. Hal tersebut telah mengacu pada prinsip-prinsip community based tourism di mana pemberdayaan masyarakat lokal sangat ditekankan pada desa wisata Berjo ini. Seluruh pelaku usaha sarana wisata boga juga turut serta dalam kegiatan komunitas. Menurut wawancara kepada salah satu pelaku usaha dan tokoh masyarakat, para pelaku usaha memiliki antusiasme tinggi dalam kegiatan pertemuan karena dengan adanya komunitas yang dinaungi oleh BUMDes, apa yang menjadi permasalahan yang dihadapi oleh para pelaku usaha dapat didiskusikan dan ditemukan solusi bersama yang menguntungkan para pelaku usaha maupun pemerintah desa.

Pemenuhan kriteria community based tourism dari segi sosial ekonomi adalah pariwisata yang terdapat di Desa Wisata Berjo tersebut telah memiliki suatu pendekatan di bidang pariwisata yang berpihak pada kaum miskin (pro-poor tourism) seperti yang dikatakan oleh Demartoto (2008). Karena sebagian besar pelaku usaha wisata boga sebelumnya merupakan petani penggarap sawah yang memiliki penghasilan tidak tetap dan setelah adanya kegiatan pariwisata tersebut peghasilan mereka lebih besar.

C. Analisis Kinerja Keterlibatan Masyarakat Dalam Sarana Wisata Penjualan Oleh-oleh menurut Community Based Tourism

Dari hasil analisis tersebut telah diketahui bahwa sebagian pelaku usaha sarana wisata penjualan oleh-oleh baik pemilik maupun pekerja merupakan penduduk lokal Desa Berjo. Selain terlihat dari keterlibatan penduduk setempat, sumber komoditas oleh-oleh tersebut sebagian juga dari wilayah lokal Desa Wisata Berjo seperti makanan ringan dan aksesoris buatan. Setelah dilakukan analisis penilaian, disimpulkan bahwa untuk pelaku sarana 
wisata penjualan oleh-oleh memiliki nilai rata-rata $92.8 \%$. Dari rentang interval yang telah digunakan, $92.8 \%$ berarti memiliki keterlibatan masyarakatnya sangat tinggi.

Kriteria community based tourism dari segi sosial dan ekonomi telah terbukti pada keterlibatan masyarat pada sarana penjualan oleh-oleh ini, di mana pelaku usaha jasa tersebut adalah warga lokal yang diberdayakan sehingga warga tersebut dapat memperoleh pekerjaan sebagai dampak positif dari kegiatan wisata yang ada di daerahnya sendiri.

D. Analisis Kinerja Keterlibatan Masyarakat Dalam Fasilitas di Lokasi Obyek Wisata menurut Community Based Tourism

Dari hasil analisis diketahui bahwa seluruh aktor pengelola merupakan warga lokal dengan skor $100 \%$. Untuk itu pengelolaan dari segi keterlibtana pelaku pada fasilitas umum wisataya tergolong sangat tinggi. Dari data yang telah disediakan di bab sebelumnya, diketahui bahwa seluruh pengelola permainan di dalam obyek wisata tersebut adalah warga lokal yang tergabung dalam kepengurusan Badan Usaha Milik Desa. Dari observasi yang dilakukan peneliti juga terlihat bahwa kondisi sarana prasrana khususnya di obyek wisata alam Grojogan Jumog memiliki kualitas yang baik. Sarana prasarana tersebut tergolong kedalam kondisi yang cukup baik dan dapat berfungsi secara maksimal.

Pemenuhan kriteria community based tourism dari segi sosial yaitu masyarakat tersebut telah diberdayakan dan memegang peranan penting di dalam obyek wisata tersebut. Pada kriteria segi politik juga dapat dilihat adanya kekuasaan komunitas yang lebih luas pada pengelolaan fasilitas obyek wisata alam Grojogan Jumog dan Telaga Madirda.

E. Analisis Kinerja Keterlibatan Masyarakat Dalam Prasarana Pengangkutan Wisata menurut Community Based Tourism

Hasil dari analisis keterlibatan masyarakat dalam prasarana wisata pengangkutan yang dilihat dari 2 aspek yakni identitas pelaku dan keikutsertaannya dalam komunitas. Diketahui bahwa keterlibatan masyarakat dalam prasarana pengangkutan wisata berupa ojek memiliki nilai $63.3 \%$ yaitu dalam kategori tinggi. Dilihat dari hasil presentasenya, hal tersebut berarti masih ada banyak pelaku yang bukan merupakan warga lokal. Meskipun demikian, hal tersebut tetap tergolong cukup baik karena memberdayakan masyarakat lokal Desa Berjo dan desa tetangga, seperti Desa Girimulyo, Kemuning, dan Punthuk Rejo yang masih termasuk dalam satu wilayah Kecamatan.

Dari data yang telah disediakan dan wawancara kepada sebagian pekerja transportasi pengangkutan wisata, sebagian besar pekerja tersebut tergabung dan aktif dalam suatu komunitas, akan tetapi terdapat juga pekerja yang tidak turut serta dalam komunitas. Sisanya dari pelaku usaha yang non-aktif biasanya mereka memiliki pekerjaan utama lainnya , sehingga mereka jarang untuk berkumpul dalam komunitas perparkiran. Komunitas perparkiran sendiri berupa pertemuan antar pelaku usaha parkir yang mengadakan arisan rutin tiap bulannya.

Prasarana wisata pengangkutan tersebut telah mengacu pada konsep community based tourism, di mana pemegang kekuasaan tertinggi berada di tangan rakyat. Prasarana pengangkutan tersebut tidak dijalankan oleh pemerintah maupun pihak swasta, akan tetapi dilaksanakan oleh masyarkat setempat.

F. Analisis Kinerja Keterlibatan

Keterlibatan masyarakat dalam prasarana wisata perparkiran dapat dilihat dari 2 aspek yakni identitas pelaku dan keikutsertaannya dalam komunitas. Perparkiran pada obyek wisata di Desa Wisata Berjo dijalankan oleh para pemuda karangtaruna Desa Berjo. 
Dari hasil tersebut dietahui bahwa kinerja prasarana parkir di obyek wisata alam grojogan jumog memiliki kinerja keterlibatan masyarakat yang sangat tinggi dengan skor $100 \%$. Sistem dari pengelolaan prasarana wisata perparkiran tersebut, petugas tersebut diganti secara bergilir sesuai dengan hasil lelang dan harus merupakan penduduk asli Desa Berjo yang tergabung dalam karangtaruna per dusun. Diketahui juga bahwa kinerja prasarana parkir menurut komunitas dalam kategori yang sangat tinggi dengan skor $100 \%$. Seluruh petugas parkir di Desa Berjo memang aktif dalam komunitas yang diadakan oleh BUMDes tersebut. Sesuai dengan prinsip community based tourism, bahwa pariwisata yang mandiri yang memiliki lembaga wisata seperti BUMDes adalah pariwisata yang telah sesuai dengan prinsip pariwisata berbasis masyarakat, asalkan fungsi dari kelembagaan tersebut dapat dioptimalkan. Hasil dari keterlibatan masyarakat menurut pelaku dan keikutsertaannnya dalam komunitas pada prasarana wisata perparkiran termasuk dalam kategori sangat tinggi.

G. Analisis Keterlibatan Masyarakat dalam Prasarana Wisata Kelembagaan dan Jasa Informasi Pariwisata menurut community based tourism

Diketahui bahwa aktor pengelola dari jasa informasi merupakan warga lokal Desar Berjo. Seluruh pengelola kelembagaan dan jasa informasi pariwisata tersebut adalah warga lokal yang tergabung dalam kepengurusan Badan Usaha Milik Desa.

Dari analisis yang telah dilakukan dapat diketahui bahwa skinerja jasa informasi pariwisata meurut aktor pengelola tergolong sangat baik dengan skor $100 \%$. Karena keseluruhan pelaku merupakan warga lokal, maka hal tersebut dapat dikatakan bahwa jasa informasi pariwisata telah mengacu pada prinsip community based tourism di mana masyarakat lokal lah yang diberdayakandalam pengelolaan wisata tersebut.
H. Analisis Pelaku Usaha pada Sarana Prasarana Pariwisata

Pada analisa penghasilan pelaku usaha sarana prasarana pariwisata menggunakan tolok ukur UMR pada Kabupaten Karanganyar. Penghasilan pelaku usaha tiap sektor dicari nilai rataratanya sehingga akan menghasilkan nilai yang menjadi took ukur per jumlah penghasilan tersebut.

Dari hasil analisis perhitungan di atas dapat dikatuhi bahwa jumlah penghasilan pelaku usaha pada beberapa sarana prasarana pariwisata di Desa Wisata Berjo sebagian besar terdapat pada tingkatan penghasilan sedang. Hal tersebut disebabkan karena usaha jasa sarana prasarana di Desa Wisata Berjo tergolong menengah ke bawah. Meskipun demikian, sedikitnya angka kemiskinan di Desa Wisata Berjo menandakan bahwa pengaruh kegiatan pariwisata berbasis masyarakat tersebut dinilai membawa dampak positif bagi masyarakat maupun Desa Wisata Berjo.

I. Analisis Kinerja Keterlibatan Masyarakat dalam Sarana dan Prasarana Pariwisata Menurut Community Based Tourism

Dari kesimpulan kinerja keterlibatan masyarakat dalam sarana prasarana pariwisata dengan konsep community based tourism pada desa wisata Berjo memiliki kategori yang sangat tinggi dengan nilai 90.9\%. Hal tersebut disimpulkan dari pengamatan penulis, akan tetapi hasilnya tidak berbeda dengan pendapat dari Dinas Pariwisata Kabupaten Karanganyar. Menurut wawancara yang dilakukan penulis dengan pihak dinas pariwisata, mereka mengatakan bahwa masyarakat memang sangat diberdayakan dalam kegiatan pariwisata yang berlangsung di Desa Wisata Berjo.

Terkait dengan BUMDesa, secara operasional telah dilaksanakan dengan baik, akan tetapi dalam pengeloaan obyek wisatanya, pihak pemerintah Desa Berjo tetap masih membutuhkan kerjasama dengan pihak pemerintah Kabupaten, artinya tidak bisa berjalan mandiri seutuhnya. Berikut ini penjelasan mengenaihasil 
dariperhitungan kinerja keterlibatan masyarakat dalam sarana prasarana pariwisata menurut community based tourism:

Tabel 2Perhitungan Keterlibatan Masyarakat

\begin{tabular}{|c|l|c|c|}
\hline NO & $\begin{array}{l}\text { Jenis Kinerja Kketerlibatan } \\
\text { Masyarakat dalam } \\
\text { Sarana/Prasarana Wisata } \\
\text { menurut CBT }\end{array}$ & Nilai & Keterangan \\
\hline 1. & $\begin{array}{l}\text { Kinerja Keterlibatan Masyarakat } \\
\text { dalam Sarana Wisata Penginapan } \\
\text { menurut CBT }\end{array}$ & $81.9 \%$ & $\begin{array}{c}\text { Sangat } \\
\text { Tinggi }\end{array}$ \\
\hline 2. & $\begin{array}{l}\text { Kinerja Keterlibatan Masyarakat } \\
\text { dalam Sarana Wisata Boga } \\
\text { menurut CBT }\end{array}$ & $98.5 \%$ & $\begin{array}{l}\text { Sangat } \\
\text { Tinggi }\end{array}$ \\
\hline 3. & $\begin{array}{l}\text { Kinerja Keterlibatan Masyarakat } \\
\text { dalam Sarana Wisata Penjualan } \\
\text { Oleh-oleh menurut CBT }\end{array}$ & $92.8 \%$ & $\begin{array}{l}\text { Sangat } \\
\text { Tinggi }\end{array}$ \\
\hline 4. & $\begin{array}{l}\text { Kinerja Keterlibatan Masyarakat } \\
\text { dalam Fasilitas di Lokasi Obyek } \\
\text { Wisata menurut CBT }\end{array}$ & $100 \%$ & $\begin{array}{l}\text { Sangat } \\
\text { Tinggi }\end{array}$ \\
\hline 5. & $\begin{array}{l}\text { Kinerja Keterlibatan Masyarakat } \\
\text { dalam Prasarana Wisata } \\
\text { Pengangkutan menurut CBT }\end{array}$ & $63.3 \%$ & Tinggi \\
\hline 6. & $\begin{array}{l}\text { Kinerja Keterlibatan Masyarakat } \\
\text { dalam Prasarana Wisata } \\
\text { Perparkiran menurut CBT }\end{array}$ & $100 \%$ & $\begin{array}{l}\text { Sangat } \\
\text { Tinggi }\end{array}$ \\
\hline 7. & $\begin{array}{l}\text { Kinerja Keterlibatan Masyarakat } \\
\text { dalamPrasaarana Wisata } \\
\text { Kelembagaan dan Jasa Informasi } \\
\text { menurut CBT }\end{array}$ & $100 \%$ & $\begin{array}{l}\text { Sangat } \\
\text { Tinggi }\end{array}$ \\
\hline \multicolumn{2}{|l|}{ Total } & $\mathbf{9 0 . 9 \%}$ & $\begin{array}{l}\text { SANGAT } \\
\text { TINGGI }\end{array}$ \\
\hline
\end{tabular}

\section{KESIMPULAN}

Pemenuhan kriteria community based tourism dari secara garis besar terlihat dari segi sosial, ekonomi dan politik. Dari segi sosial yaitu masyarakat tersebut telah diberdayakan dan memegang peranan penting dalam setiap aspek, masyarakat lokal juga telah mengelola sumberdaya \& obyek wisata tersebut, (Ardika, 2012)

Sedangkan pemenuhan kriteria community based tourism dari segi ekonomi yaitu angka pengangguran di wilayah tersebut semakin berkurang dengan adanya lapangan pekerjaan yang terbuka untuk masyarakat setempat, sehingga secara tidak langsung dapat meningkatkan pendapatan masyarakatnya. Seperti yang dikatakan salah satu pelaku usaha wisata boga, bahwa wisata boga tersebut dapat menguntungkan baginya dan bagi seluruh pelaku usaha boga, karena sebagian besar dari mereka sebelumnya merupakan petani penggarap sawah, sehingga hasil dari usaha jasa wisata tersebut dapat menambah biaya hidup bagi mereka, (Suansri dalam Nurhidayati, 2003).

Sedangkan pemenuhan kriteria community based tourism dari segi politik adalah adanya peningkatan kekuasaan komunitas yang lebih luas. Di mana dengan adanya komunitas-komunitas tersebut peran msyarakat pada kegiatan pariwisatanya semakin meningkat, (Suansri dalam Nurhidayati, 2003).

Dari beberapa kesimpulan di atas, dapat diketahui kesimpulan akhir dari penelitian ini adalah bahwa keterlibatan masyarakat dalam sarana prasarana pariwisata di Desa Wisata Berjo telah mengacu pada prinsip-prinsip community based tourism, sesuai dengan teoriteori yang memiliki arti community based tourism.

\section{REFERENSI}

Demartoto, Argyo. 2008. Pemberdayaan Perempuan dalam Pariwisata Berbasis Komunitas. Yogyakarta : Program Pascasarjana, Universitas Gajah Mada.

Ardika, Gede. 09 0ktober 2014.

"Penegembangan Kepariwisataan

Berbasisi Masyarakat.” http://digilibits.ac.id/ITS-master/pengembangankepariwisataan-berbasis-masyarakat

Nurhidayati, Sri Endah. 2012. Pengembangan Agrowisata Berkelanjutan Berbasis Komunitas di Kota Batu, Jawa Timur. Yogyakarta: Program Pascasarjana, Universitas Gajah Mada.

Sastrayuda, Gumelar S. 03 November 2013. "Hand out mata kuliah concept resort and leisure, Strategi Pengembangan dan Pengelolan Resort and Leisure". http://file.upi.edu/resort-and-leisure.html 
LAMPIRAN

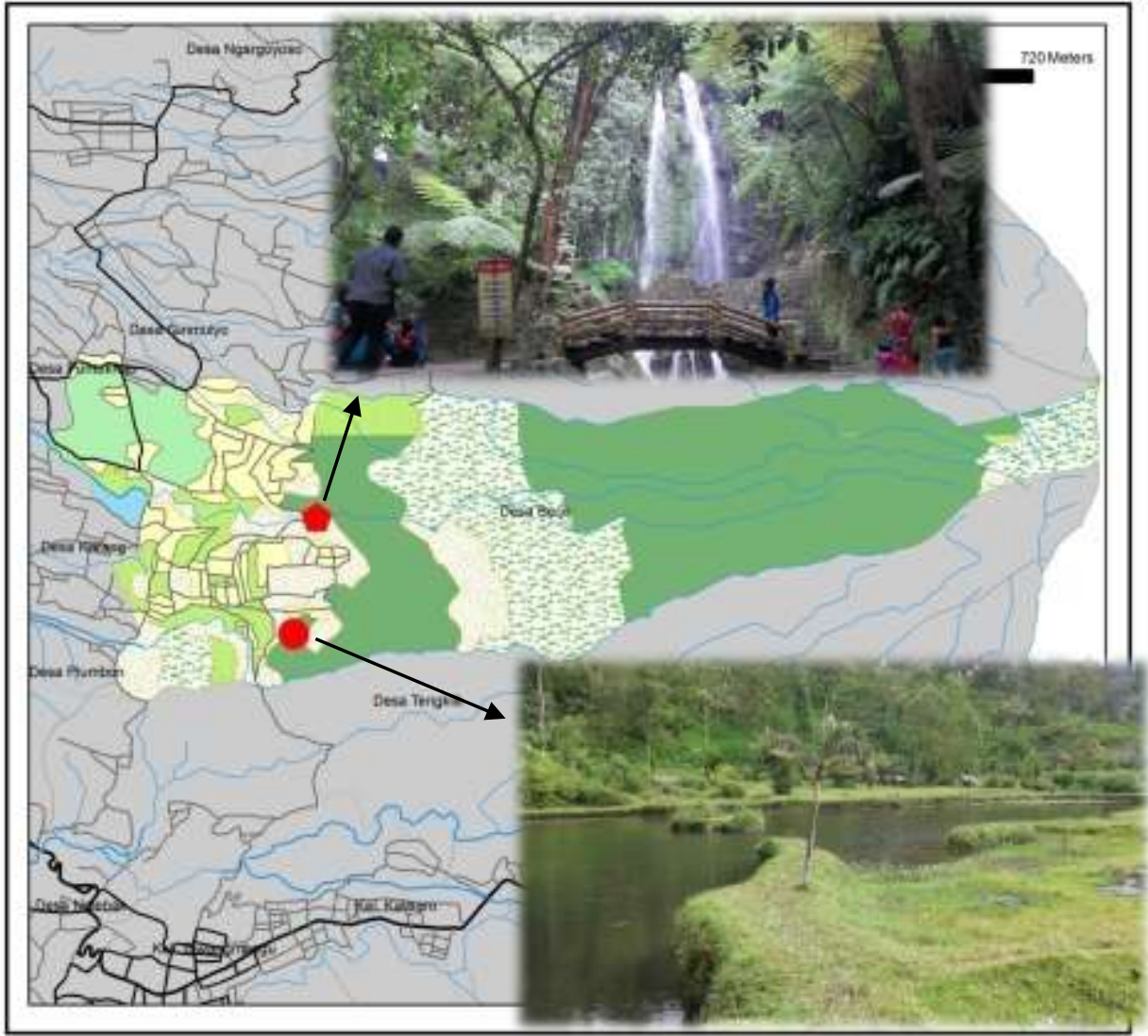

PETA OBYEK WISATA ALA DESA BERJO

the

$1: 45.000$

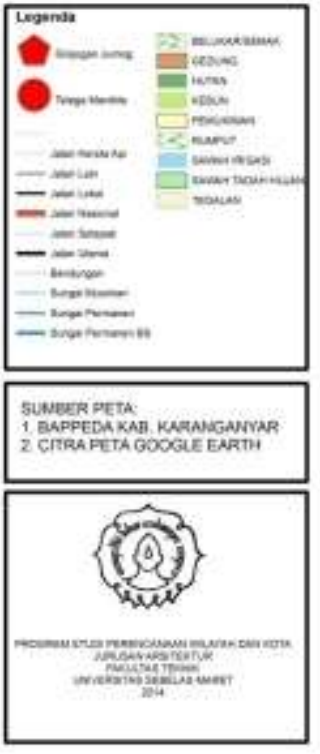

Gambar 1. Lokasi Penelitian

(Sumber: Observasi Penulis, 2015) 